\title{
The ACUARIOID AND habronematoId NemATOdes (ACUARIOIDEA, HABRONEMATOIDEA) OF THE UPPER DIGESTIVE TRACT OF WADERS A review of observations on their host and geographic distributions and transmission in marine environments
}

\author{
ANDERSON R.C.*, WONG P.L.** \& BARTLETT C.M.***
}

\section{Summary :}

Observations on the host and geographic distribution and transmission of acuarioid and habronematoid nematodes of New World waders (mainly Charadriidae and Scolopacidae) are reviewed. Fourteen species of the genus Skrjabinoclava were found in the proventriculus (rarely the oesophagus) of 13 wader species. Seven species of Skrjabinoclava each occurred in a single host and three others were found only once or twice outside the main host. Only three species occurred commonly in several wader species, mainly small Calidris spp. Host distribution is apparently dependent largely on foraging behaviour and the availability of marine crustacean intermediate hosts. Some waders however, may be refractory to infection.

Individual species of gizzard nematodes 111 species in

Schistorophinae, Seuratinae and Habronematoidea) were not confined wholly or mainly to one host but occurred in different families of waders suggesting that they may use a range of marine crustacean intermediate hosts.

Acuarioid nematodes in waders recently arrived in Iceland from Old World regions differed significantly from those found in the New World. This suggests that waders using different staging and wintering areas throughout the world may have more or less distinct species of acuarioid and habronematoid nematode parasites. This hypothesis can be tested by the comparative study of the nematodes in migrant waders in different flyways throughout the world and contrasting parasite faunas in related wader species living in separate parts of the world.

KEY WORDS : Nematoda, Acuarioidea, Habronematoidea, Charadriiformes, transmission, host-distribution, geographic distribution.

MOTS CLÉS : Nématode, Acuarioidea, Habronematoidea, Charadriiformes, transmission, distribution de l'hôte, distribution géographique.
Résumé : Les nÉmatodes (acuarioIdea, habronematoideA) DU TRACTUS DIGESTIF SUPÉRIEUR DES ECHASSIERS. REVUE DES OBSERVATIONS SUR LEUR DISTRIBUTION GÉOGRAPHIQUE CHEZ L'HÔTE ET LEUR TRANSMISSION EN MILIEU MARIN

Le spectre d'hôte, la distribution géographique et la transmission des Nématodes Acuarioidea et Habronematoidea des Echassiers du Nouveau Monde (principalement Charadriidae et Scolopacidael sont passés en revue. 14 espèces de Skrjabinoclava parasitent 13 espèces d'Échassiers. Chacune des sept espèces de Skrjabinoclava (se trouvant habituellement dans le proventriculel parasite un seul hôte et trois autres ont été trouvées seulement une ou deux fois en dehors de leur hôte principal. Seules trois espèces sont communément présentes chez plusieurs espèces d'Echassiers, principalement chez les petits Calidris. Le spectre d'hôte est apparemment largement dépendant du comportement alimentaire et de l'accessibilité du Crustacé marin hôte intermédiaire. Quelques Echassiers peuvent cependant être réfractaires à l'infection.

Certaines espèces de Nématodes du gésier 111 espèces de Schistorophinae, Seuratinae et Habronematoidea) ne sont pas inféodées totalement ou principalement à un seul hôte, mais se trouvent chez différentes familles d'Echassiers ce qui suggère qu'elles ont la possibilité d'utiliser un éventail de Crustacés marins comme hôtes intermédiaires.

Les Nématodes Acuarioidea parasites d'Echassiers récemment arrivés en Islande, venant de l'Ancien Monde, diffèrent de façon significative de ceux trouvés dans le Nouveau Monde. Ceci suggère que les Échassiers utilisant différentes aires de repos et d'hivernage à travers le monde, peuvent être parasités par des espèces plus ou moins distinctes de Nématodes Acuarioidea et Habronematoidea. Cette hypothèse peut être vérifiée par l'étude comparative des Nématodes se trouvant chez des Echassiers empruntant différents parcours migratoires dans le monde entier, par opposition à ceux se trouvant chez des espèces voisines, mais qui vivent dans des régions séparées du globe.

\section{INTRODUCTION}

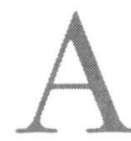

cuarioids are small nematodes commonly inhabiting the oesophagus, proventriculus and gizzard koilin of birds including waders of the

\footnotetext{
* Department of Zoology, University of Guelph, Guelph, Ontario, Canada N1G 2W1.

** Environmental Science Co-op Ltd., 520 Walker Ave., Winnipeg, Manitoba, Canada R3L 1C1.

**** Biology, University College of Cape Breton, Sydney, Nova Scotia, Canada B1P 6L2.

Correspondence: Prof. R.C. Anderson. Tel: (519) 824-4120 ext. 2715

— Fax : (519) 767-1656 — E-mail : randerso@uoguelph.ca
}

families Scolopacidae and Charadriidae. The members of the superfamily are characterized by cephalic structures in the forms of cordons, ptilina, or serrated shields (Chabaud, 1975). Species with cordons belong in the subfamily Acuariinae (there is only the single family Acuariidae in the superfamily). Cordons are grooved cuticular structures which commence near the oral opening and pass posteriorly on the lateral sides of the anterior end of the nematodes (Fig. 1). Bartlett (1991) described a gelatinous cap-like structure called a pileus around the anterior end of two acuarioid species which attach to the mucosa of the oesophagus and proventriculus of birds and suggested this 

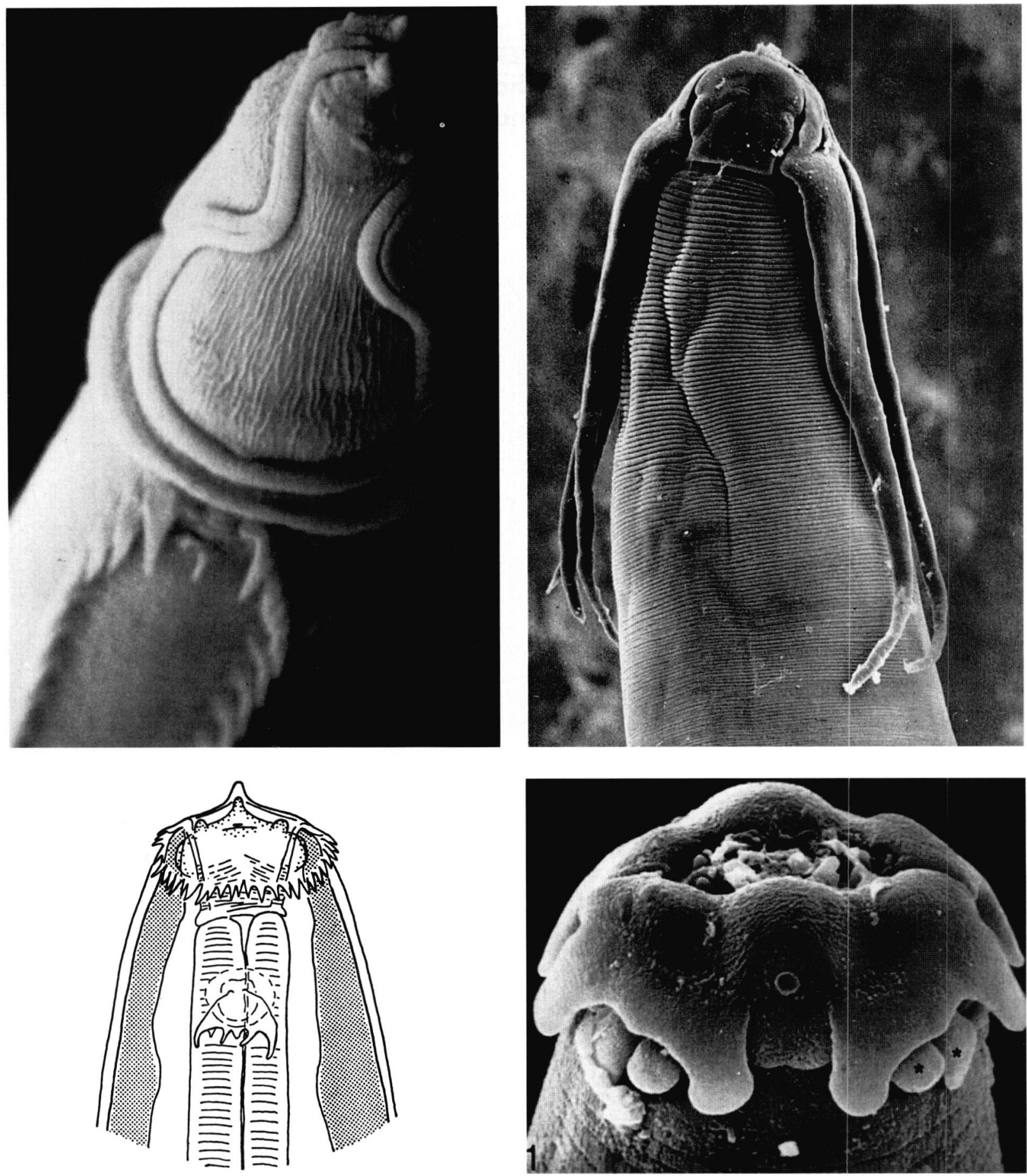

Fig. 1. - Skrjabinoclava (Acuarioidea, Acuariinae) SEM showing cordons and lateral body spines.

Fig. 2. - Schistorophus (Acuarioidea, Schistorophinae) SEM showing posteriorly directed ptilina separated from body.

Fig. 3. - Streptocara (Acuarioidea, Seuratinae) showing serrated shield at cephalic end (after Gibson, 1968).

Fig. 4. - Stellocaronema (Habronematoidea, Histocephalinae) showing leaf-like structures at cephalic end. 
structure and not the cordons, anchored the worms to the gut wall. The cordons may serve in some way to transfer food from the gut lumen of the host to the mouth of the nematode. Ptilina (Wong and Lankester, 1984) are horn or blade-like structures arising from the anterior extremity and extending posteriorly where they are detached from the underlying body cuticle (Fig. 2). Species with ptilina belong in the subfamily Schistorophinae most of which are found in the gizzard koilin of birds, particularly waders. Cordons in the form of serrated or smooth shields occur at the cephalic end of members of the Seuratiinae (Fig. 3). The function of cephalic structures in the Schistorophinae and Seuratiinae is unknown. A single habronematoid nematode, Stellocaronema skrjabini, was found in the gizzard of numerous waders. This species belongs to the subfamily Histiocephalinae, species of which have cephalic ends with complex leaf-like structures (Fig. 4).

Female acuarioids and S. skrjabini produce oval, smooth-shelled eggs which are passed in the faeces of the host. Eggs are fully larvated in utero and first-stage larvae are generally delicate and unarmed, with an elongate filamentous oesophagus and a conical or pointed tail.

The transmission of six species in the genera Acuaria, Dispharynx, and Cheilospirura parasitizing passeriform and galliform birds has been known for many years (for review see Anderson, 1992). These species found in terrestrial hosts use locusts, grasshoppers, diplopods and terrestrial isopods as intermediate hosts in which larvae develop, mainly in the muscles, to the third infective stage.

Prior to our work, four acuarioids in hosts associated with freshwater had been studied namely:

1) Desportesius invaginatus (Linstow, 1901) of the gizzard of cattle egrets (Bubulus ibis) develops to the infective stage in ostracods (Chabaud, 1950). Thirdstage larvae become encapsulated in cyprinid fish which serve as paratenic hosts.

2) Echinuria uncinata (Rudolphi, 1819) of the proventriculus of Anatidae, develops to the infective stage in cladocerans (Daphnia spp. and Ceriodaphnia sp.) as well as amphipods and ostracods (Hamann, 1893; Romanova, 1847; Garkavi, 1960; Kotelnikov, 1961; Potekhina, 1968; Misiura, 1970; Guilhon et al., 1971; Austin and Welch, 1972).

3) Streptocara crassicauda (Creplin, 1829) of the gizzard of Anatidae, develops to the infective stage in amphipods and infective larvae become encapsulated in fish (Garkavi, 1949, 1950, 1953, 1956; Kovalenko, 1960, 1963; Richter, 1960; Klesov and Kovalenko, 1967; Denny, 1969; McLaughlin and McGurk, 1987; Laberge and McLaughlin, 1989).

4) Syncuaria squamata (Linstow, 1883) of the gizzard of cormorants, reaches the infective stage in ostracods and infective larvae become encapsulated in fish (Kurochkin, 1958; Wong and Anderson, 1987a; Moravec and Scholz, 1994).

Our interest in the acuarioids of waders was sparked during field and laboratory studies of the transmission of Cosmocephalus obvelatus (Creplin, 1825) and Paracuaria adunca (Creplin, 1846) in Ring-billed Gulls (Larus delawarensis) in Lake Ontario, Canada. These species reached the infective stage in amphipods. Gulls become infected from ingesting fish paratenic hosts (Anderson and Wong, 1982; Wong and Anderson, 1982).

During these studies we discovered on two occasions a species of Skrjabinoclava Sobolev, 1943 attached to the proventriculus. The parasites were undoubtedly acquired sporadically in southern regions where the gulls spend the winter as no members of the genus were being transmitted in the breeding gull colony. Species of Skrjabinoclava are mainly found in Scolopacidae and Charadriidae and distinctions between the few species in the literature were superficial and unreliable. We added to the confusion by identifying the worms in gulls as Skrjabinoclava horrida (see Wong and Anderson, 1982), a name we now realize has been a repository of many superficially studied specimens, especially in Europe. We still do not know the status of S. horrida (Rudolphi, 1809) which should be rediscovered and redescribed from its type host, a snipe (Scolopax gallinula), in Germany; subsequent study (Wong \& Anderson, 1987) showed that the worms found sporadically in the gulls belonged to Skrjabinoclava inornatae, a common parasite of Willets (Catoptrophorus semipalmatus), and was acquired in southern regions of the hemisphere where some gulls spend the winter.

Our curiosity about the species of Skrjabinoclava in gulls prompted us to undertake a survey of the acuarioids of New World waders to determine the species present, their host and geographic distributions and, if possible, where and when transmission occurs. Biodiversity studies of this kind are especially interesting because many waders undertake seasonal, north-south migrations often over vast distances from south of the equator to northern grasslands, boreal forests and the tundra where they stay for brief periods to nest, nourished mainly by the great abundance of insect food available to them and their precocious young during the long northern summer days.

We also studied experimentally the life history of four acuarioid species in waders to give us a better understanding of our extensive field data. These data revealed for the first time the importance of marine crustaceans as intermediate hosts of some of the acuarioids of waders. However, Skrjabinocerca americana Wong and Anderson, 1992, a parasite of the oeso- 
phagus of American Avocets (Recurvirostra americana), develops to the infective stage in the freshwater amphipod, Hyalella azteca, found in ponds on the prairies of western Canada where the birds breed (Bartlett et al., 1989).

We had available for necropsy a large collection of waders from coastal marine areas in North and South America (Fig. 5). Many were collected by Dr Peter Myers, then of the Philadelphia Academy of Science, USA. Dr Myers was interested in foraging behaviour and wanted to pin-point key wintering and staging areas crucial to the survival and preservation of waders. We also obtained specimens from ornithologists in the Museum of Nature in Ottawa and the Royal Ontario Museum in Toronto, Canada. We ourselves collected on the Canadian prairies, in Ontario, the Canadian maritime provinces, and in Louisiana, USA. We also obtained waders for necropsy from Iceland; these birds were collected soon after their arrival from Old World wintering and staging areas. We performed

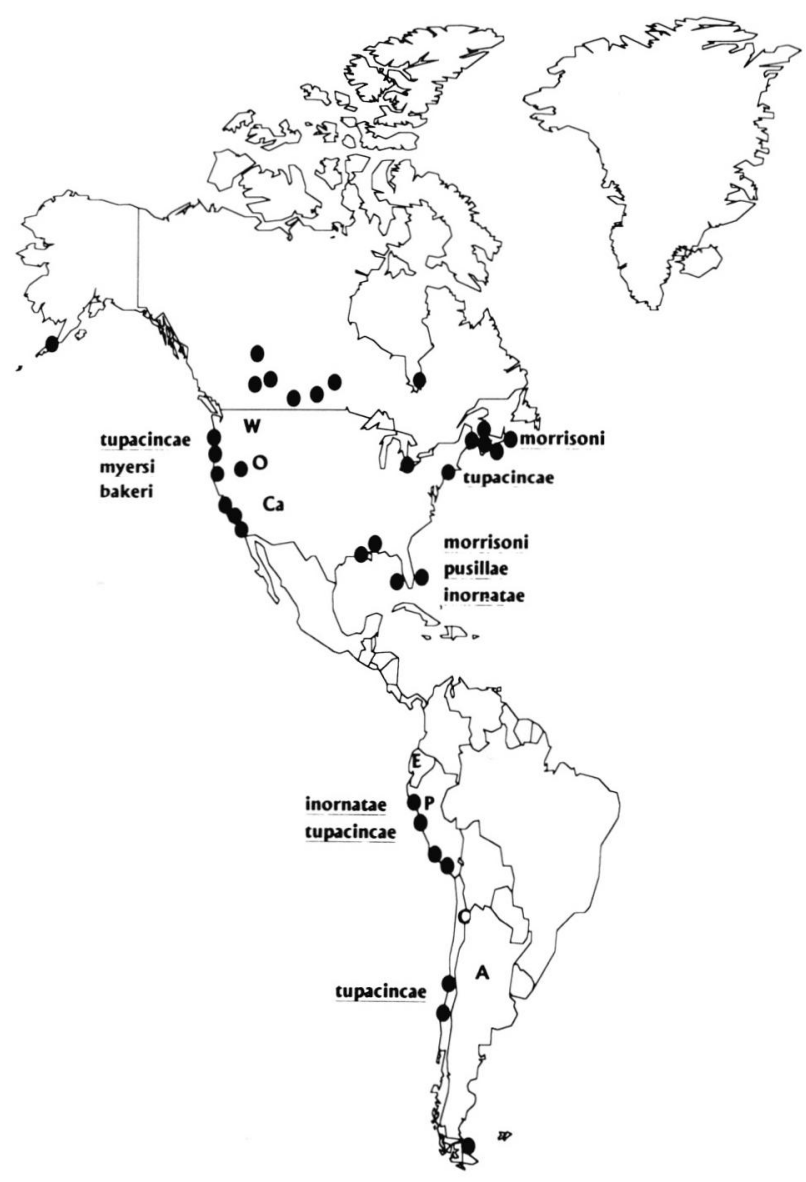

Fig. 5. - Sites where waders were collected in the New World and staging and wintering areas where species of Skrjabinoclava were shown to be transmitted as determined by identification of male fourth-stage nematodes recognizable to species. Abbreviations: $\mathrm{A}=$ Argentina, $\mathrm{C}=$ Chili, $\mathrm{Ca}=$ California, $\mathrm{E}=$ Equador, $\mathrm{O}=$ Oregon, $\mathrm{P}=$ Paraquay, $\mathrm{W}=$ Washington. necropsies on about 2,000 individual waders consisting of 41 species.

\section{SPECIES OF THE GENUS SKRJABINOCLAVA IN NEW WORLD WADERS}

Thirteen wader species were hosts to 14 species of the genus Skrjabinoclava (Table I). Twelve of the 14 species of Skrjabinoclava proved to be new, the exceptions being $S$. aculeata (Creplin, 1825) and S. tupacincae Freitas and Ibanez, 1970 (Wong and Anderson, 1987b; Anderson and Wong, 1994). Prevalences in the various infected waders were often high and some birds contained more than one species (Table II). Nevertheless, seven Skrjabinoclava spp. (aculeata, bartlettae, deltensis, hartwichi, kristscheri, semipalmatae, snorrasoni) were found in a single host only. Three other species (morrisoni, myersi, wilsonae) were found outside the main host on one or two occasions only (Table II). Three species (bakeri, pusillae and tupacincae) had wider host distributions and except for three Willets and one Black-bellied Plover (Pluvialis squatarola), and four semipalmated plovers (Charadrius semipalmatus) occurred in small waders of the genus Calidris (Table II).

$S$. inornatae of Willets occurred in only one of 31 Greater Yellowlegs (Tringa melanoleuca) (see Anderson and Bartlett, 1996) and was transferred experimentally to Marbled Godwits (Limosa fedoa) (see Wong et al., 1989) but has never been found in this latter host in the field.

It is evident, therefore, that some species of Skrjabinoclava are probably not markedly host specific. The data suggest the restricted host distributions of many of the species are related more to foraging behaviour of the birds and transmission sites than to host specificity. The presence of bakeri, pusillae and tupacincae

\begin{tabular}{lccc}
\hline \multicolumn{1}{c}{ Host } & $\begin{array}{c}\text { No. } \\
\text { exa- } \\
\text { mined }\end{array}$ & $\begin{array}{c}\text { *Prev. } \\
\text { (\%) }\end{array}$ & $\begin{array}{c}\text { No. Species } \\
\text { Skrja- } \\
\text { binoclava }\end{array}$ \\
\hline Arenaria interpres & 23 & 33 & 2 \\
Arenaria melanocephalus & 8 & 50 & 1 \\
Calidris alba & 341 & $33-92$ & 4 \\
Calidris alpina & 113 & $35-75$ & 5 \\
Calidris mauri & 93 & $75-100$ & 3 \\
Calidris minutilla & 157 & 0.4 & 1 \\
Calidris pusilla & 237 & $33-64$ & 5 \\
Catoptrophorus semipalmatus & 135 & $25-77$ & 3 \\
Charadrius semipalmatus & 33 & $17-75$ & 2 \\
Charadrius wilsonia & 4 & 100 & 1 \\
Limosa fedoa & 89 & 36 & 1 \\
Numenius phaeopus & 8 & 80 & 1 \\
Pluvialis squatarola & 83 & $23-44$ & 3 \\
\hline
\end{tabular}

* Prevalence varied according to site of collection and time of year.

Table I. - New world waders infected with species of Skrjabinoclava Sobolev, 1943. 


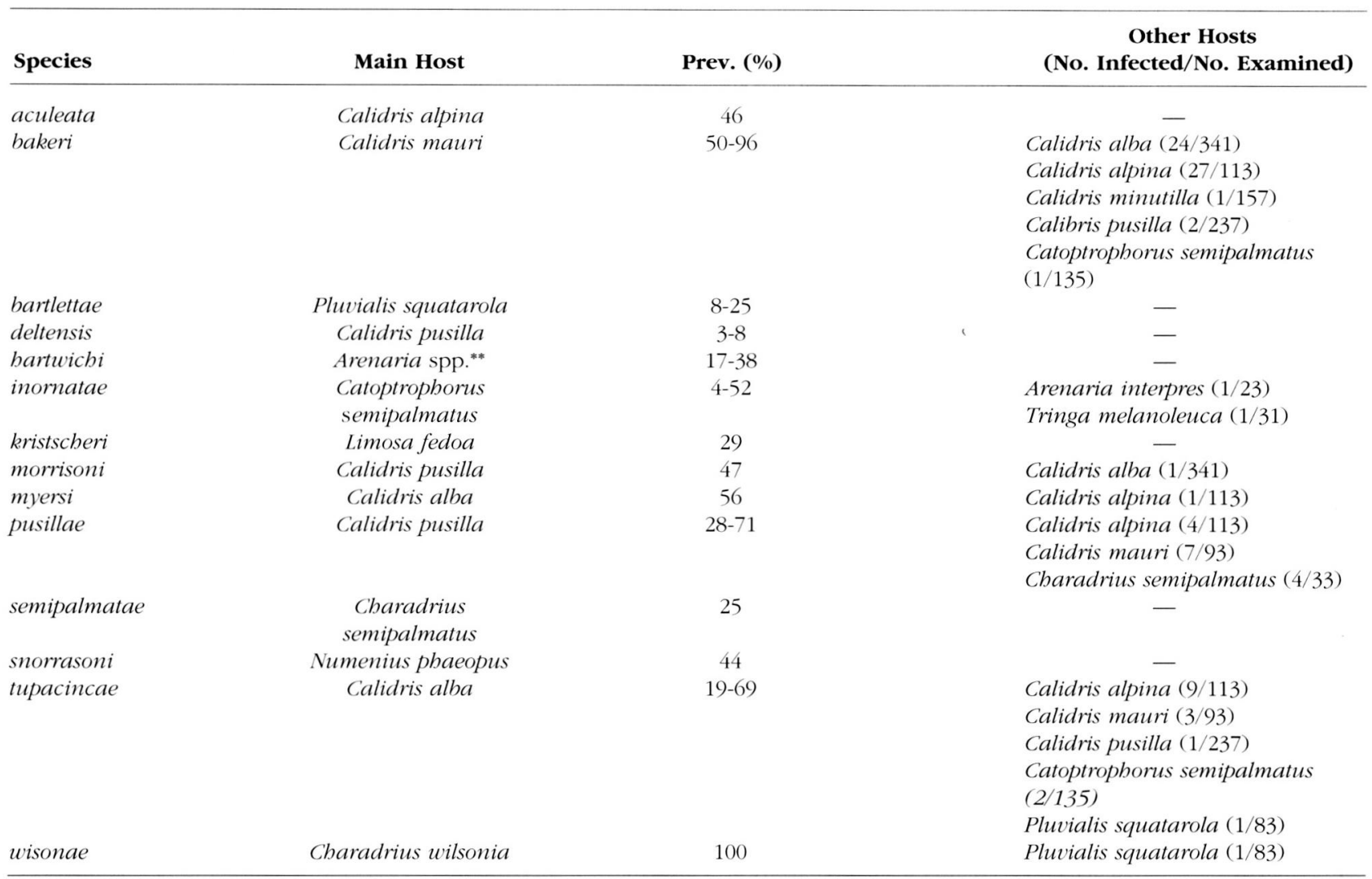

* Prevalences in main hosts sometimes varied depending on location and dates birds were collected

** Data on turnstones (Arenaria spp.) were combined.

Table II. - Main and other wader hosts of Skrjabinoclava spp. in the New World.

in a number of Calidris species indicates these waders have similar feeding strategies.

Some hosts are apparently refractory, however (Table III). For example, of 157 Least Sandpipers (Calidris minutilla) and 101 Dowitchers (Limnodromus spp.) examined, only a single individual of the former was infected, although these birds seem to share marine habitats and prey items with Sanderlings (Calidris alba) and Western Sandpipers (Calidris mauri) which are commonly infected. Experimental attempts to infect Avocets with $S$. inornata of Willets were unsuccessful (Wong et al., 1989).

Other waders like Baird Sandpipers (Calidris bairdii), Pectoral Sandpipers (Calidris melanotos), Upland Sandpipers (Bartramia longicauda) and Wilson's Phalaropes (Phalaropus tricolor) spend most of their time in freshwater habitats and would not encounter marine crustacean intermediate hosts of the genus Skrjabinoclava. We have been able to pin-point marine areas of transmission of six species of Skrjabinoclava (see Fig. 5) by recording moulting fourth-stage male worms which can be identified to species. When these were found in birds spending time in a specific region, we considered that transmission occurred in that site. Other wintering and staging sites are undoubtedly significant places of transmission as well and numerous unidentified larvae were present in many birds (Wong \& Anderson, 1990).

\begin{tabular}{|c|c|}
\hline Scolopacidae (N) & Charadriidae (N) \\
\hline Calidris bairdii (15) & Charadrius alexandrinus (9) \\
\hline Calidris fuscicollis (18) & Charadrius circumcinctus (4) \\
\hline Calidris bimantopus (7) & Charadrius collaris (2) \\
\hline Calidris melanotos (10) & Charadrius vociferus (33) \\
\hline Calidris minutilla (157) & Pluvialis dominica (6) \\
\hline \multicolumn{2}{|l|}{ Calidris ptilocnemis (45) } \\
\hline Bartramia longicauda (5) & Recurvirostridae \\
\hline Limnodromus scolopaceus (6) & Himantopus bimantopus (3) \\
\hline Limnodromus griseus (24) & Recurvirostra americana (27) \\
\hline \multicolumn{2}{|l|}{ Limnodromus sp. (71) } \\
\hline \multicolumn{2}{|l|}{ Phalaropus tricolor (56) } \\
\hline Phalaropus lobatus (44) & Haematopodidae \\
\hline Aphriza virgata & Haematopus palliatus (4) \\
\hline \multicolumn{2}{|l|}{ Tringa flavipes (29) } \\
\hline \multicolumn{2}{|l|}{ Tringa melanoleuca $(31)^{*}$} \\
\hline Gallinago gallinago (3) & \\
\hline
\end{tabular}

* Single infections were found in Calidris minutilla and Tringa melanoleuca.

Table III. - Waders (24 species) without Skrjabinoclava or with 12 rare infections. 
S. morrisoni is transmitted to Semipalmated Sandpipers (Calidris pusilla) in the Bay of Fundy, Canada through the agency of the amphipod Corophium volutator, the most important food item of Semipalmated Sandpipers staging in fall in the Bay; this has been proved by experimentation (Wong and Anderson, 1988). Larval worms were also found in birds collected in Canada soon after their arrival from the Gulf of Mexico where transmission also occurred; amphipods other than C. volutator are presumably intermediate hosts in the Gulf.

S. inornatae is a parasite of Willets. Transmission of this species takes place in the Gulf of Mexico and coastal Peru where fiddler crabs (Uca spp.) are intermediate hosts. The development of this species in crabs and Willets has been studied experimentally (Wong et al., 1989)

S. myersi is interesting because it is transmitted to Sanderlings (Calidris alba) that winter on the Pacific coast of North America but is absent in Sanderlings wintering in Chile and Peru. These latter birds migrate north through coastal California and Washington in spring but remain uninfected with $S$. myersi. Perhaps the intermediate host is the mole crab Emerita analoga (Hippidae), which might not be abundant enough in spring to sustain transmission (see Barnes and Wenner, 1968 for biology of E. analoga).

$S$. bakeri is transmitted on the coast of California in Humboldt Bay and Morro Bay. We do not rule out the possibility that Western Sandpipers coming from Alaska acquire infections in staging areas in British Columbia, Canada.

S. tupacinae is transmitted to Sanderlings and other small waders on the Pacific coast of Washington and California, USA, Chile and Peru and apparently also on the Atlantic coast of New Jersey.

S. pusillae is transmitted to Semipalmated Sandpipers in the Gulf of Mexico and most of these birds had mixed infections of $S$. pusillae and S. morrisoni.

Not every staging area is necessarily a site for the transmission of Skrjabinoclava. For example, Delaware Bay, New Jersey, USA is a major spring staging area for Ruddy Turnstones (Arenaria interpres), Red Knots (Calidris canutus), Dunlins (Calidris alpina), Semipalmated Sandpipers and Sanderlings but these birds feed there predominantly on the eggs of horseshoe crabs (Limulus polyphemus).

\section{SPECIES OF THE GENUS SKRJABINOCLAVA IN WADERS COLLECTED IN ICELAND}

To test the hypothesis that groups of waders in other regions of the world might also have their own Skrjabinoclava species transmitted in specific staging and wintering areas, we examined west African and European waders arriving in Iceland en route to their nes-

\begin{tabular}{llc}
\hline \multicolumn{1}{c}{ Species } & \multicolumn{1}{c}{ Main Host } & Prev. (\%) \\
\hline aculeata* & Calidris alpina schinzii & $15 / 22,68$ \\
albae & Calidris alba & $4 / 22,18$ \\
kristjani & Arenaria interpres & $15 / 23,65$ \\
sealyi & Charadrius hiaticula & $19 / 22,86$ \\
skulasoni & Calidris alpina schinzii & $16 / 22,73$ \\
snorrasoni & Numenius phaeopus & $12 / 20,60$ \\
vogurensis & Calidris alba & $1 / 22,5$ \\
\hline
\end{tabular}

Uninfected birds-Calidris canutus $(\mathrm{N}=19)$, Calidris maritimia $(\mathrm{N}=14)$, Tringa totanus $(\mathrm{N}=20)$, Gallinago gallinago $(\mathrm{N}=19)$, Pluvialis capricaria $(\mathrm{N}=18)$.

* Found also in New World Numenius phaeopus and Calidris alpina.

Table IV. - Main and other hosts of Skrjabinoclava spp. from waders collected in Iceland.

ting areas in Greenland and the Eastern Canadian Arctic. In this group of waders we found seven species of Skrjabinoclava, six of them new (Table IV) (Anderson \& Wong, 1992). This suggested that major geographic groupings of waders may have their own unique species of Skrjabinoclava as found in the New World.

Only two species of Skrjabinoclava were found in both the Old and the New World. S. aculeata was found in 15 of 22 Dunlins arriving in Iceland in spring. These birds had presumably wintered along the west coast of Africa and were en route to breed in Greenland and the eastern Canadian Arctic. Later we were surprised to find this species in Dunlins wintering in the Gulf of Mexico; this population breeds in the central Canadian Arctic (Anderson et al., 1994). The population of Dunlins which breeds in Alaska and winters on the Pacific coast lacks this parasite. We felt this was evidence of an historical relationship between Dunlins breeding in the central Canadian Arctic and those breeding in Iceland, Greenland and the eastern Canadian Arctic. However, this is apparently not supported by DNA analysis of the birds (Wenink et al., 1993). Possibly the parasite was introduced to eastern North American Dunlin populations by stragglers from Europe and Africa during their migrations.

S. snorrasoni has been found in Whimbrels (Numenius phaeopus) arriving in the spring in Iceland and also in Whimbrels from Nova Scotia, Canada (Bartlett \& Anderson, 1996). European Whimbrels are rather frequently reported in Nova Scotia and S. snorrasoni could have been introduced to the New World. Whimbrels are great crab-eaters and perhaps they are the source of S. snorrasoni in Whimbrels.

\section{THE GIZZARD NEMATODES IN NEW WORLD WADERS}

In addition to species of Skrjabinoclava eleven species of gizzard nematodes were found in New World waders (Table V). It was striking that these species had 


\begin{tabular}{|c|c|c|}
\hline Nematodes & $\begin{array}{l}\text { No. Host Species } \\
\text { (Bird Families) }\end{array}$ & Sites of Transmission \\
\hline $\begin{array}{l}\text { Habronematoidea } \\
\quad \text { Stellocaronema skrjabini Gilbert, } 1930\end{array}$ & $15(3)$ & Coastal Florida, USA and Peru \\
\hline \multicolumn{3}{|l|}{ Acuarioidea } \\
\hline $\begin{array}{l}\text { Ancyracanthopsis winegardi } \\
\text { Wong \& Anderson, } 1990\end{array}$ & $7(2)$ & Gulf of Mexico, USA \\
\hline $\begin{array}{l}\text { Chevreuxia americana } \\
\text { Schmidt, } 1968\end{array}$ & $7(3)$ & East of Rockies, N. Am. \\
\hline $\begin{array}{l}\text { Schistorophus skrjabini } \\
\text { Vassilkova, } 1926\end{array}$ & $3(2)$ & Pacific Coast and Gulf Coast of Mexico, USA \\
\hline $\begin{array}{l}\text { Sciadiocara bihamata } \\
\text { Mueller, } 1897\end{array}$ & $4(2)$ & 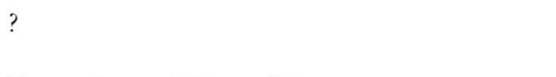 \\
\hline $\begin{array}{l}\text { Sciadiocara umbellifera } \\
\text { Molin, } 1960\end{array}$ & $9(2)$ & Texas Coast, USA and Peru \\
\hline $\begin{array}{l}\text { Sciadiocara cucullatus } \\
\text { Wehr, } 1934\end{array}$ & 1 & Texas (inland) \\
\hline $\begin{array}{l}\text { Sobolevicephalus lichtenfelsi } \\
\text { Wong \& Lankester } 1985\end{array}$ & $2(1)$ & 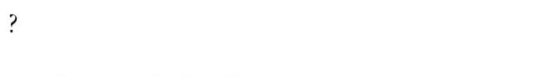 \\
\hline Streptocara sp. & $4(3)$ & Freshwater (Inland) \\
\hline $\begin{array}{l}\text { Viktorocara capillaris } \\
\text { Molin, } 1860\end{array}$ & $7(2)$ & Pacific Coast and Gulf of Mexico, USA \\
\hline $\begin{array}{l}\text { Viktorocara limosae } \\
\text { Daiya, } 1966\end{array}$ & $13(3)$ & Pacific Coast and Gulf of Mexico, USA \\
\hline
\end{tabular}

Table V. - Host distribution and sites of transmission of gizzard nematodes of New World Waders.

very wide host distributions and it was generally impossible to identify a main host as in the species of Skrjabinoclava (for details see Wong and Anderson, 1989). For example, Ancyracanthopsis winegardi was found commonly in Willets, Marbled Godwits, Longbilled Curlews (Numenius americanus), Black-bellied Plovers, Spotted Sandpipers (Actitis macularia) and Whimbrels. We have shown that this species develops in fiddler crabs (Uca spp.) in the Gulf of Mexico (Wong et al., 1989).

This wide host distribution including both small and large waders suggests that some species may use a range of marine crustacean intermediate hosts of different sizes and behaviour, including decapods, amphipods and ostracods. Also, some species may use fish paratenic hosts in transmission which would facilitate their transfer to piscivorous waders. This would be an interesting area for research as we now know several places where transmission of these parasites takes place in marine habitats (Table V).

Streptocara spp. are mainly parasites of ducks and are transmitted in freshwater through the agency of amphipods which are a major food item of dabbling ducks. The use of fish paratenic hosts ensures transmission to piscivorous ducks. The species of the genus are mainly sporadic in waders but occur fairly frequently in Avocets and Willets living in association with ducks on the Canadian prairies.

Gizzard nematodes were not found in some waders (Table VI).

\begin{tabular}{ll}
\hline Actitis macularia $(\mathrm{N}=9)$ & Heteroscelus incanus $(\mathrm{N}=1)$ \\
Apbriza virgata $(\mathrm{N}=15)$ & Numenius americanus $(\mathrm{N}=4)$ \\
Calidris bairdii $(\mathrm{N}=15)$ & Phalaropus fulicarius $(\mathrm{N}=4)$ \\
Calidris fuscicollis $(\mathrm{N}=18)$ & Phalaropus lobatus $(\mathrm{N}=44)$ \\
Calidris melanotos $(\mathrm{N}=10)$ & Tringa melanoleuca $(\mathrm{N}=31)$ \\
Calidris ptilocnemis $(\mathrm{N}=45)$ & Tringa flavipes $(\mathrm{N}=29)$ \\
Gallinago gallinago $(\mathrm{N}=3)$ &
\end{tabular}

Table VI. - New world waders without gizzard nematodes.

\section{GIZZARD AND OTHER NEMATODES}

(OTHER THAN SKRJABINOCLAVA SPP.), IN WADERS COLLECTED IN ICELAND IN SPRING

A new genus and species, Voguracuaria lankesteri, was found in the oesophagus of Whimbrels and a new species, Skrjabinocerca europaea, was found in the oesophagus of the Common Ringed Plover (Charadrius biaticula) (Table VII) (Wong \& Anderson, 1993). The related species of Skrjabinocerca in the New World are S. americana (Wong \& Anderson, 1993) of Avocets and S. bennetti Bartlett \& Anderson, 1996 of Whimbrels (Numenius phaeopus). S. americana is transmitted in freshwater using amphipod intermediate hosts (Bartlett et al., 1989).

Only two of the nine species of gizzard worms found in Iceland were also identified in the New World, namely, Viktorocara limosae and Sciadiocara bibamata. The species in the New World related to Ancyracanthopsis schikhobalovi is $A$. winegardi which uses fiddler crabs as intermediate hosts (Wong \& Anderson, 


\begin{tabular}{|c|c|c|c|c|}
\hline Species & Main Host & Prev., \% & $\begin{array}{l}\text { Other Host } \\
\text { (Prev., \%) }\end{array}$ & $\begin{array}{l}\text { Site } \\
\text { in Host }\end{array}$ \\
\hline \multicolumn{5}{|l|}{ Habronematoidea } \\
\hline $\begin{array}{l}\text { Stellocaronema skrjabini } \\
\text { Gilbert, } 1930\end{array}$ & Charadrius biaticula & $4 / 22,18$ & - & Gizzard \\
\hline \multicolumn{5}{|l|}{ Acuarioidea } \\
\hline $\begin{array}{l}\text { Ancyracanthopsis schikhobalovi } \\
\text { Guschanskaya, } 1950\end{array}$ & Numenius phaeopus & $14 / 20,70$ & - & Gizzard \\
\hline $\begin{array}{l}\text { Chevreuxia revoluta } \\
\text { Sobolav, Rudolphi, } 1819\end{array}$ & Charadrius biaticula & $2 / 22,9$ & - & Gizzard \\
\hline $\begin{array}{l}\text { Schistorophus cornutus } \\
\text { Sobolev, } 1943\end{array}$ & Numenius phaeopus & $1 / 20,5$ & - & Gizzard \\
\hline $\begin{array}{l}\text { Schistoropbus cirripedesmi } \\
\text { Rhizhikov \& Khokhlova, } 1964\end{array}$ & Numenius phaeopus & $1 / 20,5$ & - & Gizzard \\
\hline $\begin{array}{l}\text { Sciadiocara bibamata } \\
\text { (Mueller, 1897) }\end{array}$ & Numenius phaeopus & $3 / 20,15$ & $\begin{array}{l}\text { Arenaria interpres } \\
(2 / 23,9)\end{array}$ & Gizzard \\
\hline $\begin{array}{l}\text { Skrjabinocerca europaea } \\
\text { Wong \& Anderson, } 1993\end{array}$ & Charadrius biaticula & $6 / 22,27$ & $\begin{array}{l}\text { Calidris alpina } \\
\quad(1 / 22,5)\end{array}$ & Oesophagus \\
\hline $\begin{array}{l}\text { Viktorocara charadrii } \\
\text { Belopolskaja, } 1954\end{array}$ & Charadrius biaticula & $1 / 22,5$ & - & Gizzard \\
\hline $\begin{array}{l}\text { Viktorocara limosae } \\
\text { Daiya, } 1966\end{array}$ & Charadrius biaticula & $1 / 22,5$ & $\begin{array}{l}\text { Calidris alpina } \\
\quad(2 / 22,9)\end{array}$ & Gizzard \\
\hline $\begin{array}{l}\text { Voguracuaria lankesteri } \\
\text { Wong \& Anderson, } 1993\end{array}$ & Numenius phaeopus & $8 / 20,40$ & - & Oesophagus \\
\hline
\end{tabular}

Acuarioids other than Skrjabinoclava spp. were not found in Calidris canutus $(\mathrm{N}=22)$, Calidris maritimia $(\mathrm{N}=22)$, Calidris alba $(\mathrm{N}$ 22), Gallinago gallinago $(\mathrm{N}=20)$, Tringa totanus $(\mathrm{N}=22)$ and Pluvialis apricaria $(\mathrm{N}=20)$.

Table VII. - Acuarioid nematodes other than Skrjabinoclava spp. in waders collected in spring in Iceland.

1990b). Whimbrels from Iceland often contained infective larvae belonging to Ancyracanthopsis. Presumably these were acquired from eating crabs, probably before arriving in Iceland.

\section{Pathogenesis}

We have no information on the pathogenic effects of acuarioid or habronematoid nematodes on waders. Generally, the intensities of proventricular and gizzard worms were small or moderate (Wong \& Anderson, 1990, 1991, 1996). However, we have collected 176 adult $S$. myersi in a single Sanderling from California and have found up to 520 larvae, probably belonging to $S$. myersi and $S$. tupacincae, in an individual sanderling. Individual Marbled Godwits had up to 87 Stellocaronema skrjabini and one Wilson's Plover had 165 Viktorocara capillaris. It is difficult to believe that such heavy infections are not harmful but we have no proof. Generally, the acuarioids and their many wader hosts seem well adapted to each other.

\section{CONCLUSIONS}

Our results suggest that waders nesting in the northern hemisphere and wintering in different coastal regions in the southern hemisphere are likely to have diffe- rent acuarioid nematodes based on their migratory patterns and faithfulness to specific marine staging and wintering areas where transmission takes place through the agency of marine crustacean intermediate hosts. This hypothesis can be tested by additional research. Of the 214 species of waders some $43 \%$ nest in the northern hemisphere and many stage and winter in coastal marine environments in the southern hemisphere (Hayman et al., 1986). Of these, some small waders like Sanderlings and Dunlins and larger waders such as the Black-bellied Plover have Holarctic breeding distributions and the various populations have widely different staging and wintering areas. The various populations of each species should have more or less distinct species of acuarioids.

In addition, the acuarioid fauna in related bird species living in different parts of the world should now be contrasted. A good example would be the Black-tailed Godwit (Limosa limosa) which breeds in Europe and winters in Africa and southeast Asia and Australia and the Marbled Godwit which breeds on the prairies in the United States and Canada and winters on the Pacific and Gulf coasts of North and Central America. Such biodiversity studies might help us to understand how these parasite fauna's evolved and are maintained and also help us to test hypotheses about the 
post-glacial distribution of various migrant waders throughout the world. It may be possible sometimes to relate breeding populations of waders in the northern hemisphere to specific staging and wintering areas on the basis of their acuarioid parasites. For example, sanderlings breeding in the arctic and infected with Skrjabinoclava myersi would probably belong to that population of birds which winter on the Pacific coasts of North America. This parasite is apparently absent in the population of sanderlings wintering on the Pacific coast of South America.

Finally, waders are easy to raise and maintain in captivity for experimental work. We have incubated the eggs and raised with little difficulty Avocets, Willets, Godwits and Long-billed Curlews. Also, we have kept adult Semipalmated Sandpipers in captivity for prolonged periods with little trouble. Since the birds are precocial and independent upon hatching they require much less attention than the young of gulls and passeriforms which need constant attention and are subject to various diseases resulting from artificial feeding and handling.

\section{ACKNOWLEDGEMENTS}

T he study on shorebird nematodes was supported by operating grants from the Natural Sciences and Engineering Research Council of Canada to RCA and CMB. We again express our appreciation to the National Research Council of Iceland which gave us permission to obtain migrant shorebirds in that country. The individuals there who helped us in one way or another were Dr Siggi Snorrasson, Dr Skuli Skulason and Kristjan Lilliendahl.

\section{REFERENCES}

Anderson R.C. The Nematode Parasites of Vertebrates, their Development and Transmission. CAB International, Wallingford, UK, 1992, $578 \mathrm{p}$.

ANDERSON R.C. \& BARTLETT C.M. Skrjabinoclava inornatae Wong and Anderson, 1987 (Nematoda: Acuarioidea) as a sporadic parasite of the Greater Yellowlegs Tringa melanoleuca Gmelin (Aves: Scolopacidae). Systematic Parasitology, 1996, 33, 127-129.

Anderson R.C. \& Wong P.L. The transmission and development of Paracuaria adunca (Creplin, 1846) (Nematoda: Acuarioidea) of gulls (Laridae). Canadian Journal of Zoology, 1982, 60, 3092-3104.

Anderson R.C. \& Wong P.L. Western Palaerctic and Ethiopian species of Skrjabinoclava (Nematoda: Acuarioidea) in Icelandic shorebirds (Aves: Charadriiformes) en route to breed in the New World and Greenland. Canadian Journal of Zoology, 1992, 70, 1861-1877.
Anderson R.C. \& WONG P.L. New species of Skrjabinoclava (Nematoda: Acuarioidea) from the Semipalmated Sandpiper (Calidris pusilla) Aves: Scolopacidae. Journal of the Helminthological Society of Washington, 1994, 61, 64-66.

Anderson R.C., Wong P.L. \& Bartlett C.M. Skrjabinoclava aculeata (Acuarioidea: Acuariidae) in Dunlins (Calidris alpina) from both Iceland and Louisiana, USA Journal of the Helmintbological Society of Washington, 1994, 61, 129132.

Austin F.G. \& Welch H.E. The occurrence, life cycle, and pathogenicity of Echinuria uncinata (Rudolphi, 1819) Soloviev, 1912 (Spirurida, Nematoda) in waterfowl at Delta, Manitoba. Canadian Journal of Zoology, 1972, 50, 385-393.

BARnes N.B. \& WenNer A.M. Seasonal variation in the sand crab Emerita analoga (Decapoda, Hippidae) in the Santa Barbara area of California. Limnology and Oceanography, $1968,13,465-475$.

BARTLETT C.M. A new hypothesis concerning attachment of parasitic nematodes (Spirurida: Acuarioidea) to the upper alimentary tract of birds. Canadian Journal of Zoology, 1991, 69, 1829-1833.

Bartlett C.M. \& Anderson R.C. Acuarioid nematodes in Whimbrels (Numenius phaeopus budsonicus) transient in late summer in Cape Breton, Nova Scotia, Canada. Journal of the Helminthological Society of Washington, 1996, 63, 89-92.

Bartlett C.M., Anderson R.C. \& Wong P.L. Development of Skrjabinocerca prima (Nematoda: Acuarioidea) in Hyalella azteca (Amphipoda) and Recurvirostra americana (Aves: Charadriiformes), with comments on its precocity. Canadian Journal of Zoology, 1989, 67, 2883-2892.

Chabaud A.G. Cycle évolutif de Synhimantus (Desportesius) spinulatus (Nematoda Acuariidae). Annales de Parasitologie Humaine et Comparée, 1950, 25, 150-166.

Chabaud A.G. No. 3. Keys to genera of the Order Spirurida. Part. 2. Spiruroidea, Habronematoidea and Acuarioidea. In: Anderson R.C., Chabaud A.G. and Willmott S. (eds), CIH Keys to the Nematode Parasites of Vertebrates. CAB International, Wallingford, UK, 1975, 29-58.

DENNY M. Life cycle of helminth parasites using Gammarus lacustris as an intermediate host in a Canadian lake. Parasitology, 1969, 59, 795-827.

GARKAVI B.L. A study of the life cycle of the nematode Streptocara crassicauda (Creplin, 1829) parasitic in domestic and wild ducks (In Russian). Doklady Akademii Nauk SSSR, 1949, 65, 421-424.

GARKAVI B.L. Reservoir hosts of Streptocara crassicauda (Creplin, 1829), a parasite of domestic ducks (in Russian). Trudi Vsesoyuznogo Instituta Gelmintologii, 1950, 4, 5-7.

GARKAVI B.L. The life cycle of the nematode Streptocara crassicauda. Diagnosis and epizootiology of streptocariasis of ducks (in Russian). Trudi Vsesoyuznogo Instituta Gelmintologii, 1953, 5, 5-22.

GARKAVI B.L. The propagation and natural foci of the Streptocara nematodes of ducks (in Russian). Zoologicheskii Zhurnal, 1956, 35, 376-378.

GARKAVI B.L. Observations on the biology of Echinura unci- 
nata and epizootiology of the infection in ducks in the Krasnodar Territory. I (Abstract) (in Russian). Tezigy Doklady Nauchnoi Konferentsii Vsesoyuznogo Obshchestiva Gelminthologeskii, Moscow, 1960, 15-20 Dec. 1960, 28-29.

GiBson G.G. Species composition of the genus Streptocara Railliet et al., 1912 and the occurrence of these avian nematodes (Acuariidae) on the Canadian Pacific coast. Canadian Journal of Zoology, 1968, 46, 629-645.

Guilhon J., Saratsiotis A. \& Jolivet G. Experimental echinuriasis in ducks. Recueil de Médecine Vétérinaire de l'école d'Alfort, 1971, 147, 1-21.

Hamann O. Die Filarienseuche der Enten und der Zwischenwirt von Filaria uncinata R. Zentralblatt für Bakteriologie und Parasitenkunde, 1893, 14, 555-557.

Hayman P., Marchant J. \& Prater T. Shorebirds, an identification guide to the waders of the world, Christopher Helm, London, UK, 1986. 412 p.

KuROCHKIN Y.V. Study of nematodes of the genus Skrjabinoclava Kuraschvili. Trudy Astrakbanskogo Gosudarstvennogo Zapovednika, 1958, 4, 325-336.

KLEsov M.D. \& Kovalenko I.I. The biology, epizootiology and prophylaxis of helminths of ducks on the Azov coast (in Russian). Veterinariya Kiev, 1967, No. 11, 3-7.

Kotelnikov G.A. Biology of Echinuria uncinata from ducks (in Russian). Sbornik Nauk Informastsii Vsesoyuznogo Instituta Gelmintologii K.I. Skrjabin, 1961, No 7/8, 30-33.

KOVAlENKO I.I. Study of the life cycle of some helminths of domestic ducks from farms on the Azov coast (in Russian). Doklady Akademii SSSR, 1960, 133, 1259-1261.

KOVALENKO I.I. Endemic of mixed infections with Streptocara, Tetrameres and Polymorphus in fowls (in Russian). Trudi Ukrainskogo Respublikanskogo Nauchnogo Obshchestva Parazitologov, 1963, 2, 137-140.

Laberge R.J.A. \& McLaughlin J.D. Hyalella azteca (Amphipoda) as an intermediate host of the nematode Streptocara crassicauda. Canadian Journal of Zoology, 1989, 67, 2335-2340.

McLaughuin J.D. \& McGurk B.P. An analysis of gizzard worm infections in fall migrant ducks at Delta, Manitoba, Canada. Canadian Journal of Zoology, 1987, 65, 1470-1477.

Misiura M. Development of Echinuria uncinata (Rud., 1819) larvae (Nematoda) in Cladocera and Ostracoda. Acta Parasitologica Polonica, 1970, 17, 247-251.

Moravec \& Scholz. Observations on the development of Syncuaria squamata (Nematoda: Acuarioidea), a parasite of cormorants, in the intermediate and paratenic hosts. Folia Parasitologia, 1994, 41, 183-192.

POTEKHINA L.F. Epizootiology of echinuriasis of birds (in Russian). Trudi Vsesoyuznogo Instituta Gelmintologii, 1968, 14, 263-271.

RiCHTER S. Intermediate host of Streptocara pectinifera (Neumann, 1900), life cycle and infestation mode of this parasite (in Russian). Veterinarski Arhiv, 1960, 30, 86-92.

Romanova N.P. A study of the development cycle of Echinuria uncinata Rud., 1819: nematode parasite of the stomach of natatores (in Russian). Comptes Rendus Doklady de l'Academie des Sciences de l'URSS, 1947, 55, 371-372.

Wenink P.W., BAKER A.J. \& Tilanus. Hypervariable control region sequences reveal global population structuring in a long-distant migrant shorebird, the dunlin (Calidris alpina). Proceeding of the National Academy of Science, 1993, 90, 94-98.

WONG P.L. \& ANDERSON R.C. The transmission and development of Cosmocephalus obvelatus (Nematoda: Acuarioidea) of gulls (Laridae). Canadian Journal of Zoology, 1982, 60, 1426-1440.

Wong P.L. \& ANDERSON R.C. Development of Syncuaria squamata (Linstow, 1883) (Nematoda: Acuarioidea) in ostracods (Ostracoda) and double-crested cormorants (Phalacrocorax auritus auritus). Canadian Journal of Zoology, 1987a, 66, 2524-2531.

Wong P.L. \& ANDERSON R.C. New and described species of Skrjabinoclava Sobolev, 1943 (Nematoda: Acuarioidea) of the proventriculus of nearctic waders (Aves: Charadriiformes) with a review of the genus and a key to species. Canadian Journal of Zoology, 1987b, 65, 2760-2779.

WONG P.L. \& ANDERSON R.C. Skrjabinoclava bartlettae n. sp. (Nematoda: Acuarioidea) from the Black-bellied Plover (Pluvialis squatarola (L.)) (Charadriiformes: Charadriidae). Canadian Journal of Zoology, 1988a, 66, 2262-2264.

WONG P.L. \& ANDERSON R.C. Transmission of Skrjabinoclava morrisoni Wong and Anderson, 1988 (Nematoda: Acuarioidea) to semipalmated sandpipers (Calidris pusilla (L.)) (Charadriiformes; Scolopacidae). Canadian Journal of Zoology, 1988b, 66, 2265-2269.

WONG P.L. \& ANDERSON R.C. Host and geographic distribution of Skrjabinoclava spp. (Nematoda: Acuarioidea) in nearctic shorebirds (Aves: Charadriiformes) and evidence for transmission in marine habitats in staging and wintering areas. Canadian Journal of Zoology, 1990a, 68, 2539-2552.

Wong P.L. \& ANDERSOn R.C. Ancyracanthopsis winegardi n. sp. (Nematoda: Acuarioidea) from Pluvialis squatarola (Aves: Charadriidae) and Ancyracanthopsis heardi n. sp. from Rallus longirostris (Aves: Rallidae), and a review of the genus. Canadian Journal of Zoology, 1990 b, 68, 1299-1306.

Wong P.L. \& ANDERSON R.C. Distribution of gizzard nematodes (Habronematoidea : Acuarioidea) of New World shorebirds (Charadriiformes), with special reference to localities of transmission. Canadian Journal of Zoology, 1991, 69, 2579-2588.

Wong P.L. \& Anderson R.C. New and described species of nematodes from shorebirds (Charadriiformes) collected in spring in Iceland. Systematic Parasitology, 1993, 25, 187-202.

Wong P.L., Anderson R.C. \& Bartlett C.M. Development of Skrjabinoclava inornatae (Nematoda: Acuarioidea) in fiddler crabs (Uca spp.) (Crustacea) and western willets (Catoptrophorus semipalmatus inornatus) (Aves: Scolopacidae). Canadian Journal of Zoology, 1989, 67, 2893-2901.

Wong P.L. \& ANDERSON R.C. Erratum in Host and geographic distribution of Skrjabinoclava spp. (Nematoda: Acuarioidea) in nearctic shorebirds (Aves: Charadriiformes) and evidence for transmission in staging and wintering areas. Can. J. Zool. 68, 2239-2552. Canadian Journal of Zoology, 1996, 74, 1378.

WONG P.L. \& LANKESTER M.W. Revision of the genus Schistorophus Railliet, 1916 (Nematoda: Acuarioidea). Canadian Journal of Zoology, 1984, 62, 2527-2540. 